\title{
ANALISA DAN PERANCANGAN E-SERVICE PORTAL UNTUK CALON MAHASISWA BARU PADA BINUS UNIVERSITY
}

\author{
Eli Suryani; Robby Wijaya; Ricornus Pranata Wijaya; Novita Maria Valentina
}

\author{
Jurusan Sistem Informasi, Fakultas Ilmu Komputer, Universitas Bina Nusantara \\ Jln K.H. Syahdan No. 9, Palmerah, Jakarta Barat 11480 \\ dc_eli@binus.edu
}

\begin{abstract}
The purpose of this study is to analyze and design the application of e-service portal to help Marketing BINUS university to improve the speed and ease of service for Prospect students with the integration of transaction and information services required prospective students, and can be presented in a personalized to adds its own interesting experience for user. It would create a competitive advantage of the University which also potentially triggering an increase in the number of intake students. The methodology used is the method of analysis, which reviews and interviews conducted directly to the field, distributing questionnaires, observing and analyzing the data and needs, and using the design method, which includes design of business models, user interface design and database design. Results to be achieved is a web portal, where the system can facilitate prospective students to obtain the desired information services in full, and with a presentation that can be personalized and make transactions easier and faster. Conclusions obtained are BINUS University can take advantage of e-service in a web portal for prospective new students as supporting its competitive advantage in the utilization of information technology and support one of its primary missions to create service excellence in all fields.
\end{abstract}

Keywords: application, e-service, portal, basis data, web

\begin{abstract}
ABSTRAK
Tujuan penelitian ini adalah menganalisis dan merancang aplikasi e-service portal pada BINUS University untuk membantu meningkatkan kecepatan dan kemudahan dalam layanan bagi para calon mahasiswa dengan pengintegrasian layanan transaksi dan informasi yang dibutuhkan calon mahasiswa, serta dapat dipresentasikan secara terpersonalisasi sehingga menambah pengalaman yang menarik tersendiri bagi pemakainya,. Hal tersebut akan menjadi keunggulan kompetitif dari Universitas yang juga akan memicu peningkatan jumlah calon mahasiswa. Metodologi yang digunakan adalah metode analisis, dimana diadakan tinjauan dan wawancara langsung ke lapangan, menyebarkan kuesioner, mengamati dan menganalisis data dan kebutuhan, serta menggunakan metode perancangan, yang mencakup perancangan model bisnis, rancangan layar dan perancangan basis data. Hasil yang ingin dicapai adalah web portal, di mana sistem ini dapat memudahkan calon mahasiswa untuk mendapatkan layanan informasi yang diinginkan secara lengkap,dan dengan presentasi yang dapat dipersonalisasi serta melakukan transaksi lebih mudah dan cepat. Simpulan yang didapat adalah BINUS University dapat memanfaatkan e-service dalam web portal untuk calon mahasiswa baru sebagai penunjang keunggulan kompetitifnya dalam pemanfaatan teknologi informasi dan mendukung salah satu misi utamanya untuk menciptakan layanan yang prima disegala bidang.
\end{abstract}

Kata kunci: aplikasi, e-service, portal, basis data, web 


\section{PENDAHULUAN}

Seiring dengan perkembangan, BINUS University sekarang sudah semakin berkembang dengan adanya berbagai fakultas dan jenis jenjang yang tersedia. Dengan demikian, semakin luas dan banyak pula yang merupakan potensi dan atau calon mahasiswa yang akan mengenyam pendidikan di BINUS University. potensi dan atau calon mahasiswa adalah calon mahasiswa atau siapapun baik itu para lulusan SMA/sederajat, karyawan,dan lulusan S1, yang tertarik untuk mengeyam pendidikan di BINUS University. Calon mahasiswa ini kemudian mendorong BINUS University untuk memberikan layanan yang lebih baik kepada calon siswa yang akan belajar di BINUS University.

Hal tersebut diatas mendukung BINUS University untuk selalu mengembangkan layanan yang ada. Beberapa layanan dalam bentuk website yang dapat diakses dilingkungan eksternal untuk Prospect Students seperti: Website BINUS (www.binus.ac.id), Daftar Online, (www://information.binus.ac.id/admisionline, Website BINUS (www.binus.ac.id), Daftar Online (www://information.binus.ac.id/admisionline), BINUS Career (www.binuscareer.com), BINUS Entrepreneurship Center (http://www.binus.ac.id/bec), Bee-Tube (http://bee-tube.binus-access.com), Bee-Watch (http://www.binus-access.com/bee-watch), Bee-Forum (http://www.binus-access.com/beeforum), Bee-Phone (http://v2.binus-access.com/newportal/phone), dan lain-lain. Website-website yang disediakan ini terletak pada alamat yang berbeda, sehingga banyak website yang harus dibuka oleh potensial dan atau calon mahasiswa untuk mendapatkan semua informasi yang ada, sehingga kemungkinan besar untuk tidak mendapatkan informasi dan layanan secara menyeluruh dan lengkap yang seharusnya mereka dapat akses, sehingga mengakibatkan informasi tidak dikomunikasikan maksimal.

Didasarkan pada permasalahan tersebut, BINUS University memerlukan sebuah jendela yang mampu mengintegrasikan informasi yang dibutuhkan oleh potensial calon mahasiswa. Oleh karena itu, kami mengusulkan aplikasi yang disebut My BINUS Desk. My BINUS Desk ini adalah sebuah eservices dengan web portal yang mampu menyediakan semua informasi yang terdapat pada berbagai website BINUS University, khususnya menyediakan informasi yang dibutuhkan oleh potensial calon mahasiswa. Sistem ini merupakan sebuah keunggulan kompetitif yang diharapkan mampu untuk memaksimalkan semua informasi yang terdapat pada Website-website BINUS University, sehingga dapat bermanfaat untuk potensial calon mahasiswa dan bagian pemasaran BINUS University.

\section{METODE}

Metode yang digunakan dalam penyusunan ini meliputi dua bagian pokok, yaitu: Metode Analisis, Analisa sistem dilakukan dilakukan melalui empat tahapan, yaitu (1) survey dan wawancara atas sistem yang sedang berjalan di Admisi BINUS University, (2) pengumpulan data kuesioner atas informasi yang diperlukan prospect Student, (3) analisis hasil kuesioner dan wawancara (4) identifikasi kebutuhan informasi. Hasil analisis kemudian akan digunakan sebagai resume untuk masukan dalam perancangan sistem yang diusulkan.

Lalu, Metode Perancangan: Dalam penyusunan ini metode perancangan proses bisnis yang digunakan adalah Metode Object Oriented Analysis and Design (OOAD), (2) Pembuatan dan rancangan User Interface serta Site Map, (3) Pembuatan Rancangan Basis data dan ERD.

\section{Tinjauan Pustaka}

\section{Internet}


Menurut Laudon dan Laudon (2004: 282), internet adalah jaringan internasional dari jaringanjaringan yang merupakan kumpulan dari jaringan privat dan publik. Menurut McLeod (2001: 73), internet mungkinkan suatu jaringan komunikasi global yang tidak hanya menghubungkan para mitra dagang, tetapi juga mencakup para pelanggan. Menurut Thompson et al (2003: 161), internet adalah jaringan dari jaringan dan merupakan kumpulan dari jaringan komputer yang berhubungan.

Internet suatu fenomena perubahan dalam komputer dan telekomunikasi. (O’Brien, 2004: 107). Jadi dapat disimpulkan bahwa internet adalah kumpulan dari jaringan

komputer internasional baik privat maupun publik.

\section{E-Services}

Menurut Lamersdorf et al (2004: xi), dasar teknis dari e-servicesdibangun dari aplikasiaplikasi komputer yang secara dramatis mendukung interaksi yang kompleks ("transaksi data") antara partner kerja heterogen dalam sudut pandang mereka sebagai konsumen, bisnis ataupun agen pemerintahan (dalam berbagai kombinasi yang mungkin terjadi). Namun hasil komunikasi terdistribusi tersebut tidak dapat diimplementasikan tanpa kontribusi tambahan yang terdiri dari sistem informasi termasuk aspek keamanannya juga. E-Services dibawakan secara elektronis, melalui internet. Sebagai contoh dari e-services termasuk software solutions yang disediakan oleh Application Service Providers, dan Rantai Suplai jaringan manajemen informasi. Gabungan e-services adalah sebah grup dari beberapa e-services yang dapat dilihat sebagai alur kerja. Sebuah workflow adalah sebuah proses bisnis otomatis yang mengatur urutan aktivitas kerja dan penggunaan sumber daya yang berhubungan dengan banyak langkah. Komposisi ini cenderung statis dan terhubung dengan topic application integration (EAI).

Menurut Yee (2006: vii), sebuah e-service memiliki karakteristik sebagai berikut: Layanannya dapat diakses melalui internet, Layanannya dijalankan melalui software aplikasi (service software) yang dimiliki oleh sebuah provider (biasanya sebuah perusahaan), Perangkat lunak layanan milik perusahaan memungkinkan kita menggunakan, perangkat lunak milik perusahaan lain dalam rangka menjalankan layanannya., sebuah provider dapat memiliki lebih dari satu layanan, Layanan tersebut dikonsumsi atau digunakan oleh seorang atau oleh aplikasi lain yang mengakses layanan tersebut melalui internet. Biasanya ada biaya yang dibayarkan pengguna layanan kepada pihak penyedia layanan. Konsumen memiliki preferensi privasi dan keamanan tertentu dalam layanan yang tidak boleh diganggu oleh provider. Menurut Yee (2006: 141) sebuah sistem e-service membuat pengumpulan data menjadi sangat mudah dan menggunakan integrasi, interkoneksi, dan teknologi data mining.

\section{Portal}

Portal adalah aplikasi berbasis web. Aplikasi ini menyediakan akses suatu titik tunggal dari informasi online terdistribusi, seperti dokumen yang didapat melalui pencarian, berita dan link ke situs khusus. Untuk memudahkan pengguna biasanya disediakan kemampuan pencarian dan pengorganisasian informasi. Pada kenyataannya bila kita telusuri maka akan kita temukan berbagai macam portal di internet. Di samping itu pula portal juga dalam perkembangannya tidak hanya mendukung satu komunitas tapi beberapa komunitas. Portal juga mendukung berbagai macam layanan yang membedakannya dengan website HTML biasa. (Prakoso, 2003: 1)

\section{Web Portal}

Menurut Zabir (2008: 2), sebuah web portal adalah sebuah halaman yang mengijinkan user untuk mengkostumisasi home page-nya dengan melakukan drag dan drop widget. Pendekatan ini memberikan kontrol penuh kepada user atas konten apa yang dilihat pada home page-nya, di mana 
halaman web tersebut adalah halaman yang ingin dilihat oleh user, dan bagaimana user tersebut berinteraksi dengan konten tersebut. Dengan web portal, setiap pengunjung web site dapat mengkostumisasi dan mengatur tampilannya sesuai dengan yang mereka inginkan untuk dilihat kembali ketika mereka kembali berkunjung. Yang terbaik, layout-nya disimpan per-user. Berikut ini adalah fitur-fitur yang terdapat pada web portal:

- Single touch point: portal menjadi gateway yang tunggal dan tersentralisasi untuk arus informasi.

- Collaboration: member-member pada portal dapat berkomunikasi satu sama lainnya melalui portal.

- Content and document management: portal biasanya menyediakan layanan untuk mengantur dokumen, yang mana termasuk creation, authoring, approval, version control, publishing, indexing, dan searching.

- Customization: member-member pada portal biasanya mempunyai kebebasan dalam menentukan konten dan layanan yang mereka inginkan dan bagaimana konten-konten tersebut ditampilkan ke browser mereka.

- Integration: koneksi antara fungsi dan data dari berbagai sistem dalam komponen yang baru.

- Access control: akses ke layanan dan sumber daya bisa dibatasi dengan skema role-based ketika member portal melakukan login. (Prakoso, 2003)

\section{HASIL DAN PEMBAHASAN}

\section{Analisa Sistem yang Berjalan pada Admisi (Marketing) BINUS University}

Berikut ini adalah Rich Picture yang menggambarkan tentang rangkaian kegiatan bagian Pemasaran BINUS University yang terkait langsung dengan potensial calon mahasiswa, yang akan menunjukkan aliran proses dan informasi yang belum maksimal dan efisien, sebagai berikut:

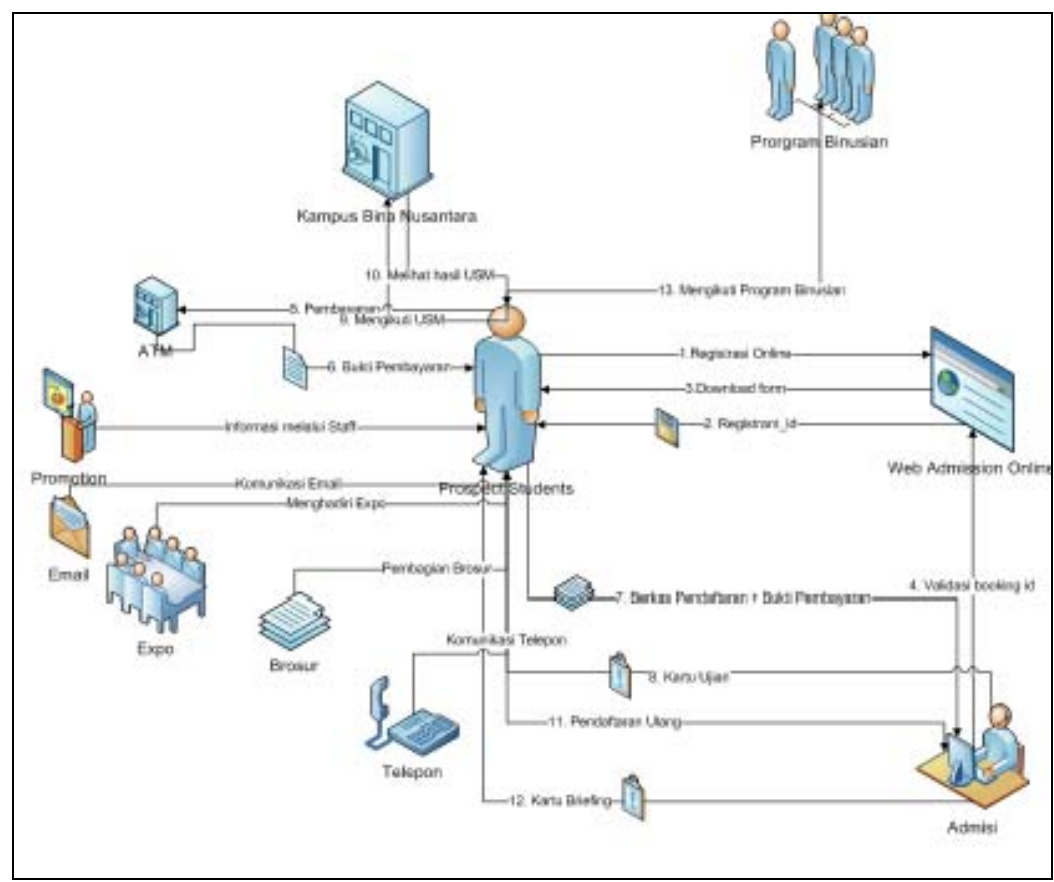

Gambar 1 Rich Picture Sistem yang Berjalan pada Admisi BINUS University 


\section{Analisa Penentuan Pertanyaan Kuesioner}

Beberapa point penting sebagai bahan analisa yang didapatkan dari hasil kuesioner adalah dengan membagi pertanyaan kepada 3 sub bagian sebagai berikut:

Pertama, informasi tentang latar belakang dan minat responden terhadap penggunaan internet dan fitur-fiturnya, dengan menggali Latar belakang responden, latar belakang responden dalam penggunaan internet, fitur-fitur yang sering diakses dalam internet dan menjadi kebutuhan. Kedua, informasi-informasi yang dibutuhkan dan yang dapat menarik responden untuk mengunjungi situs sebuah Universitas dan mendaftar pada Universitas tersebut, dengan cata menggali beberapa informasi sebagai berikut: faktor ketertarikan yang menarik bagi reponden untuk melanjutkan pendidikan (kuliah), informasi yang menarik bagi responden mengenai Universitas, informasi yang dibutuhkan sebelum mendaftar. Ketiga, informasi fitur tambahan yang diminati dan dapat digunakan sebagai personalisasi bagi user: fitur-fitur yang membantu dalam mendapat informasi dari universitas, kebutuhan fitur yang diinginkan responden

\section{Hasil Penyebaran Kuesioner}

Penyebaran kuesioner dilakukan secara acak dengan berbagai latar belakang melalui penyerabaran lembar kuesioner dan melalui internet. Jumlah populasi untuk potensial calon mahasiswa berdasarkan data yang didapat dari pihak Marketing BINUS University melalui wawancara dan survey adalah sebanyak 8717 orang (dilakukan pembulatan sampai 8000 orang).

Untuk penentuan sampel jumlah populasi dicocokan dengan data tabel 2.1 pada Bab2 (p.24), maka jumlah sampel yang harus dipenuhi dengan taraf kesalahan 10\% adalah sebanyak 263 orang. Berikut beberapa highlight yang didapatkan dari hasil kuesioner : Sebesar 46,99\% atau 39 responden menyatakan sangat sering mengakses internet (setiap hari), sebesar $61,45 \%$ atau 51 responden tertarik untuk melanjutakan kuliah ke universitas swasta, 65,06\% atau 54 responden dalam 1 minggu, waktu yang digunakan adalah sekitar 1-5 jam, 21,00\% atau 63 tanggapan bahwa prioritas utama yang dilakukan responden adalah mengakses jaringan komunitas online (Facebook, Friendster, Multiply, dll.), Sebesar 61,45\% atau 51 responden tertarik untuk melanjutkan kuliah ke universitas swasta, sebesar $96.39 \%$ atau 80 responden menyatakan tertarik akan informasi seputar dunia kampus dan perkuliahan, 100\%) tertarik dengan proses registrasi yang cepat, mudah, serta aman melalui internet, $97,60 \%$ atau 81 responden setuju dengan adanya pendaftaran masuk universitas secara online, 19,54\% atau 59 tanggapan menyatakan bahwa fitur yang diinginkan ada pada situs universitas adalah fitur yang mempunyai banyak informasi terkini tentang kampus, 96,39\% atau sebanyak 80 responden setuju dengan adanya universitas yang menyediakan situs portal informasi untuk layanan responden, 9,47\% atau 45 tanggapan menyatakan bahwa informasi mengenai program beasiswa sebagai salah satu informasi yang ingin diketahui oleh responden tentang universitas sebelum mendaftar

\section{Hasil Wawancara}

Menurut pihak Management Marketing Admisi, aktivitas yang paling banyak dilakukan oleh mahasiswa potensial adalah bertanya mengenai informasi mengenai jurusan, biaya masuk, serta informasi-informasi lainnya yang terkait dengan pendaftaran. Aktivitas lainnya yang mempunyai load tertinggi adalah pada saat daftar ulang (pengumpulan berkas).

\section{Analisa kebutuhan Fitur yang Dibutuhkan}

Berikut adalah fitur yang akan dikembangkan pada aplikasi e-service portal pada bagian Pemasaran BINUS University yang diberi nama My BINUS Desk. 


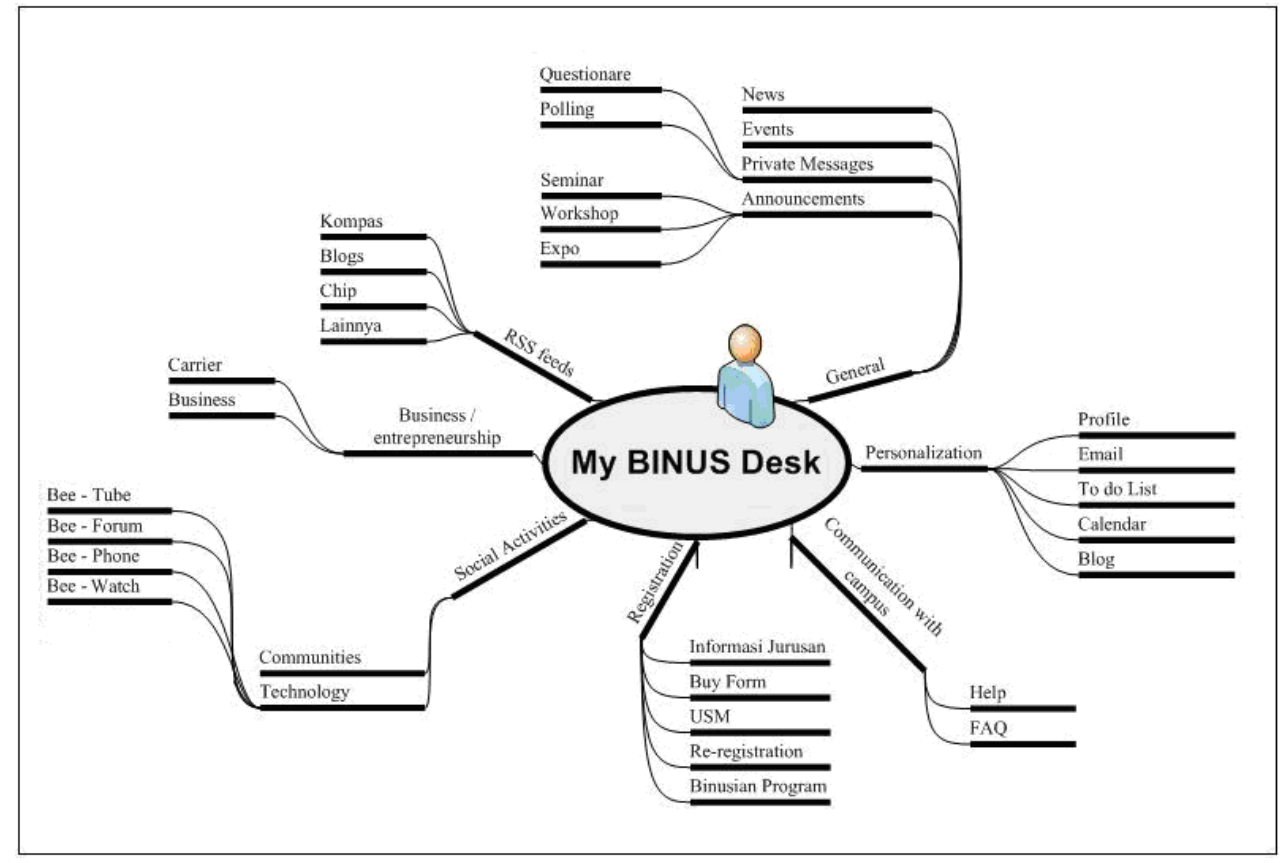

Gambar 2 Fitur Sistem yang Diusulkan

\section{Analisa Sistem yang Diusulkan}

Rich Picture berikut adalah gambaran perubahan bisnis proses yang terjadi pada Marketing BINUS University bagian Admisi setelah diimplementasikan sistem yang disulkan:

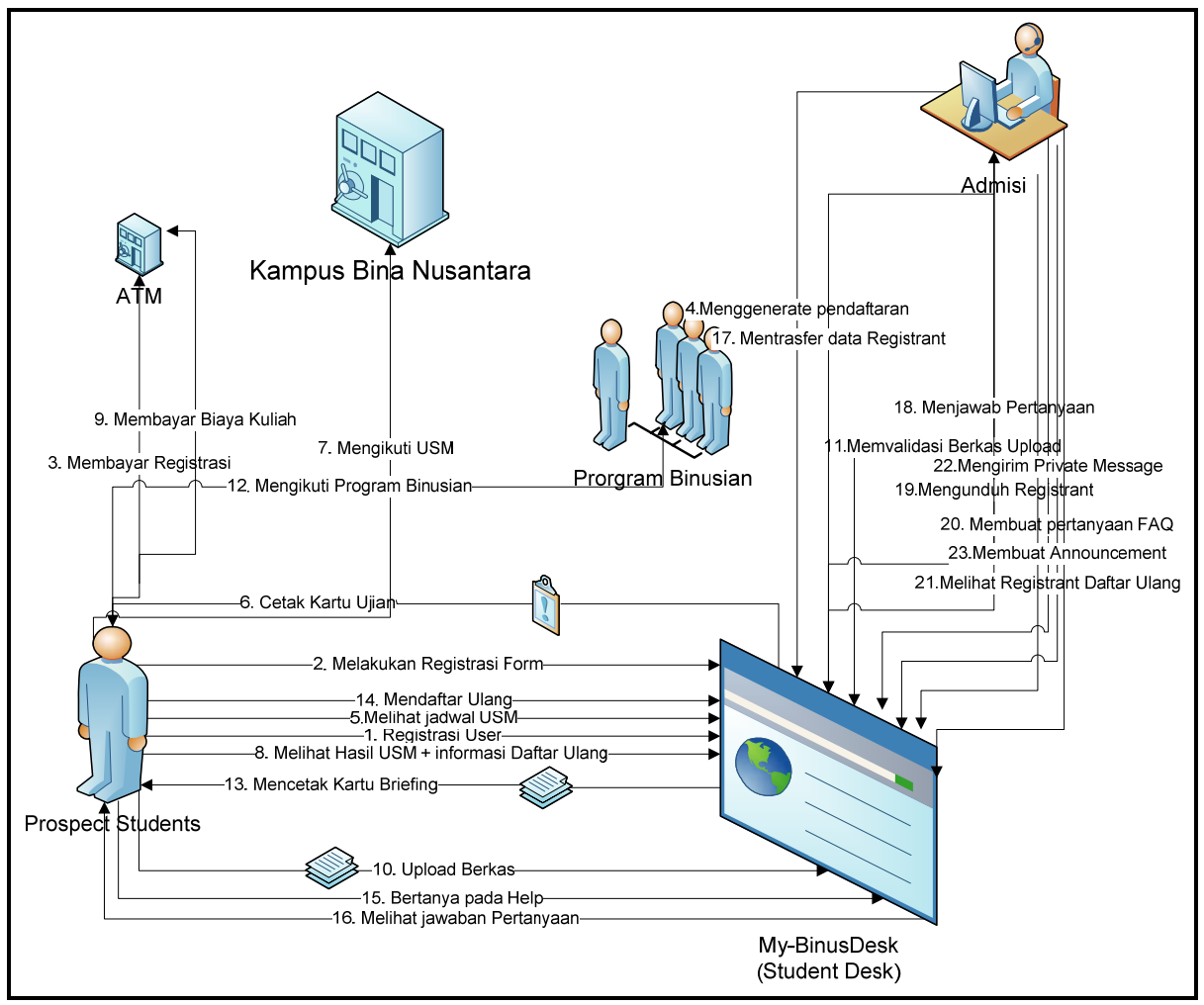

Gambar 3. Rich Picture Sistem yang Diusulkan pada Admisi BINUS University 


\section{Rancangan Basis Data}

\section{Fungsi Aplikasi Back End dan Front End}

Gambar Berikut menjelaskan interaksi antara Admin Admisi dengan My BINUS Desk sebagai Back End dan Front End dari website.

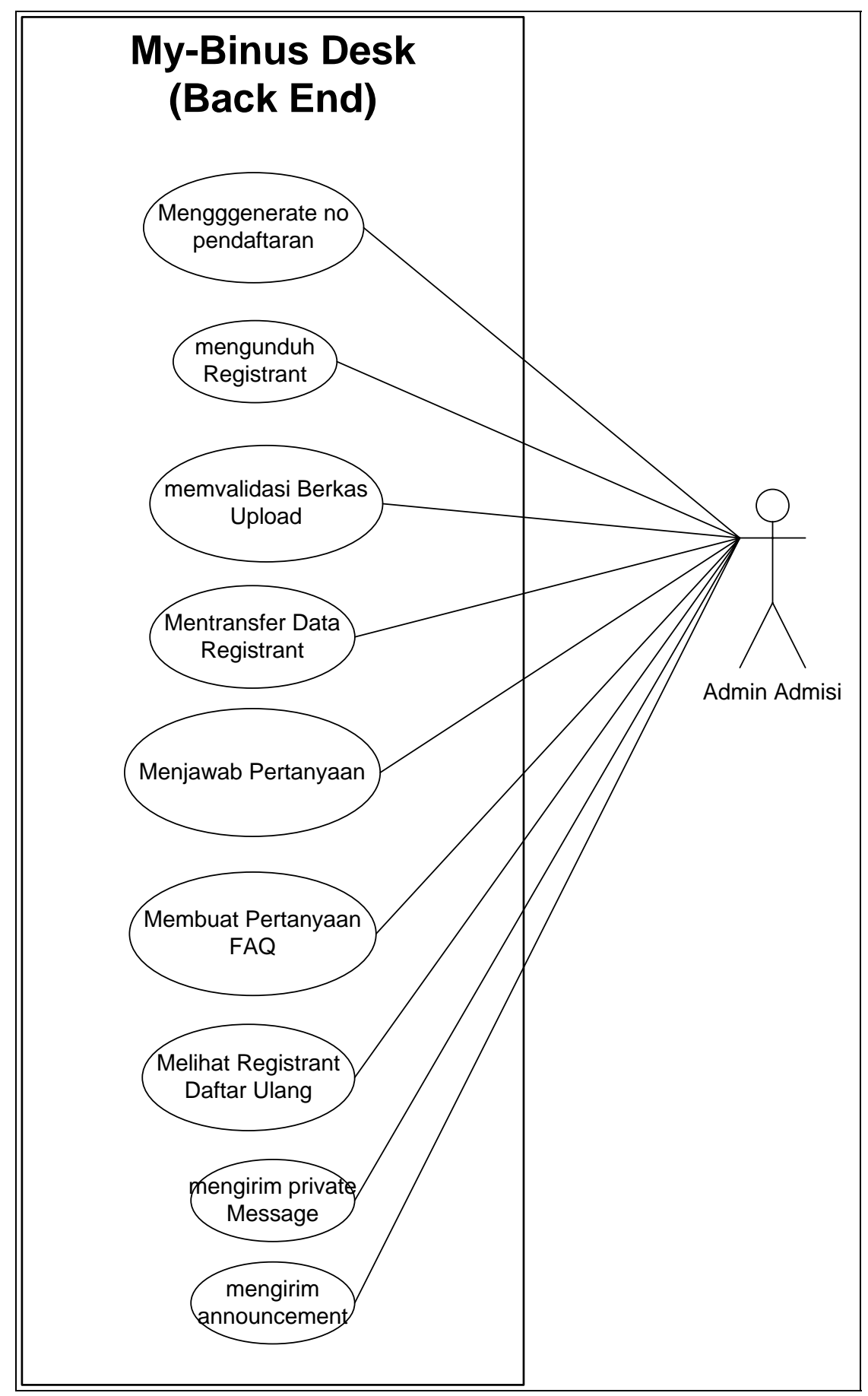

Gambar 4 Use Case My BINUS Desk (Back End) 


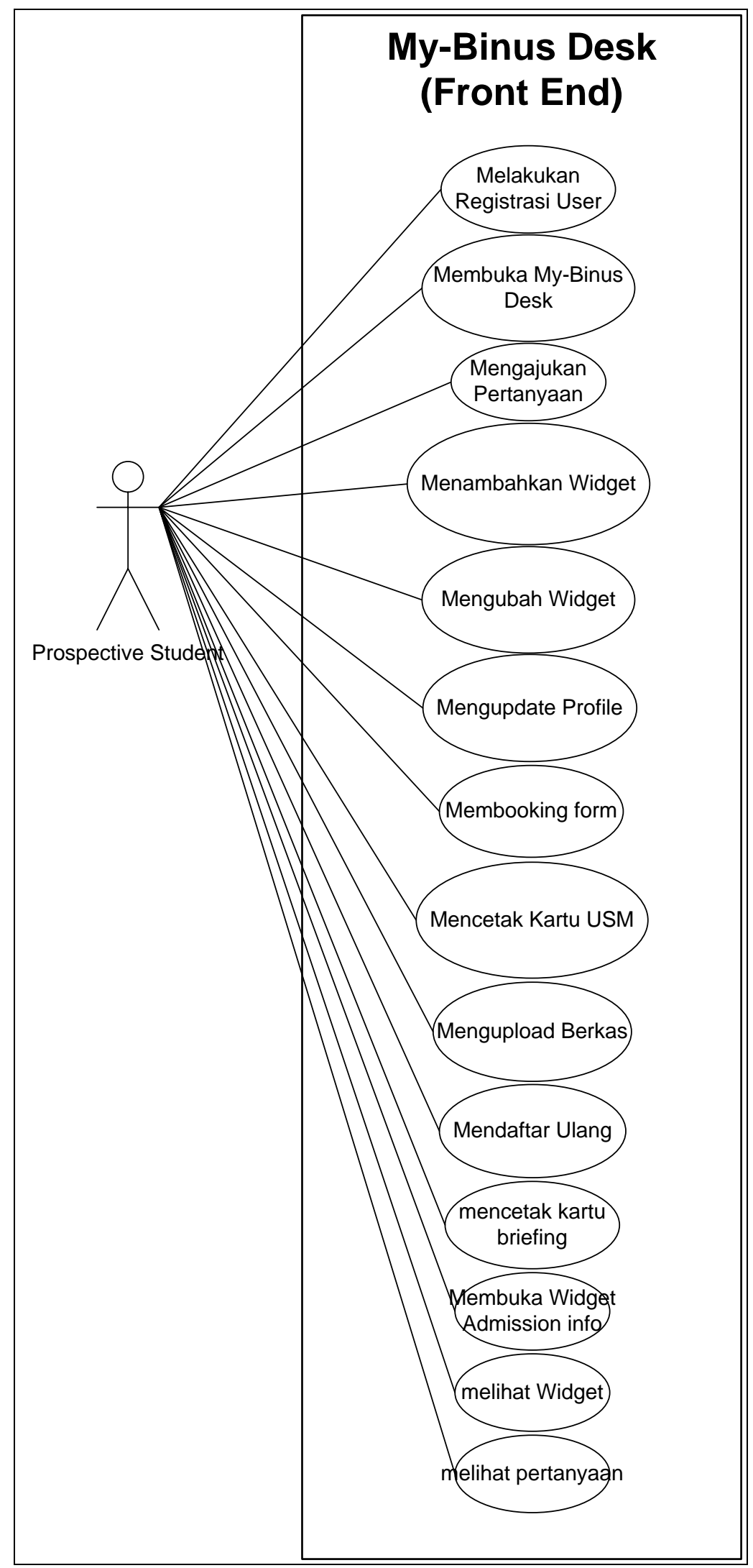

Gambar 5 Use Case My BINUS Desk (Front End) 


\section{Rancangan Layar}

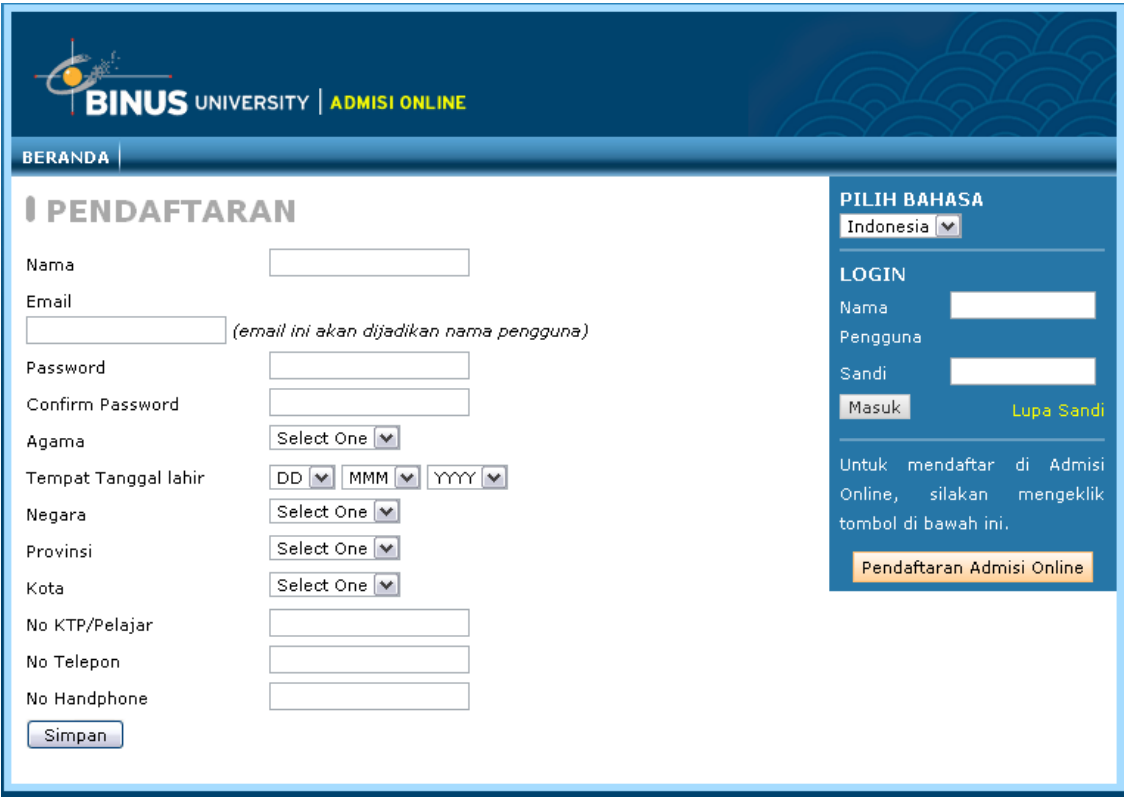

Gambar 6 Rancangan Layar untuk Registrasi User

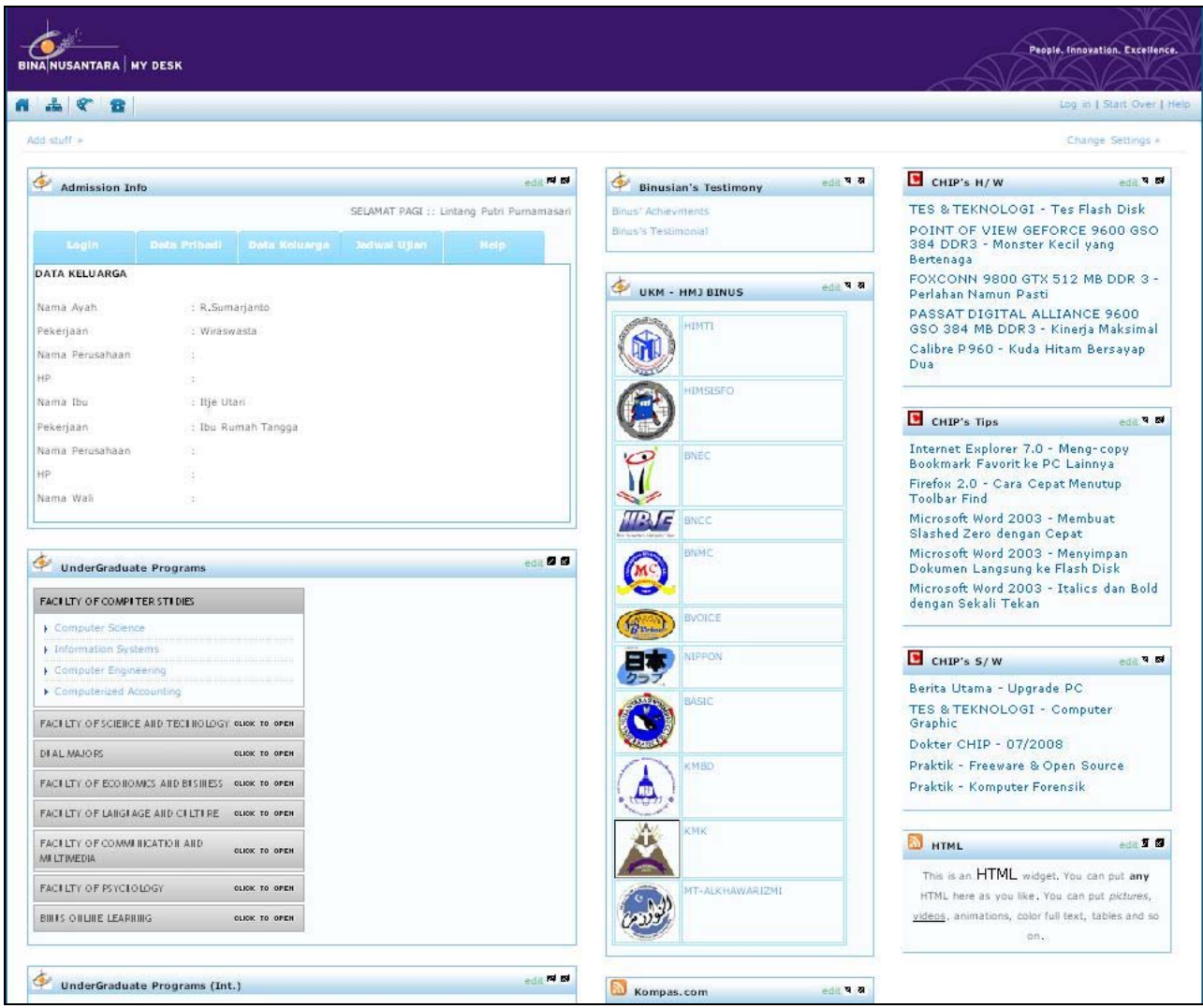

Gambar 7 Rancangan Layar Tampilan Halaman Utama Setelah Login 

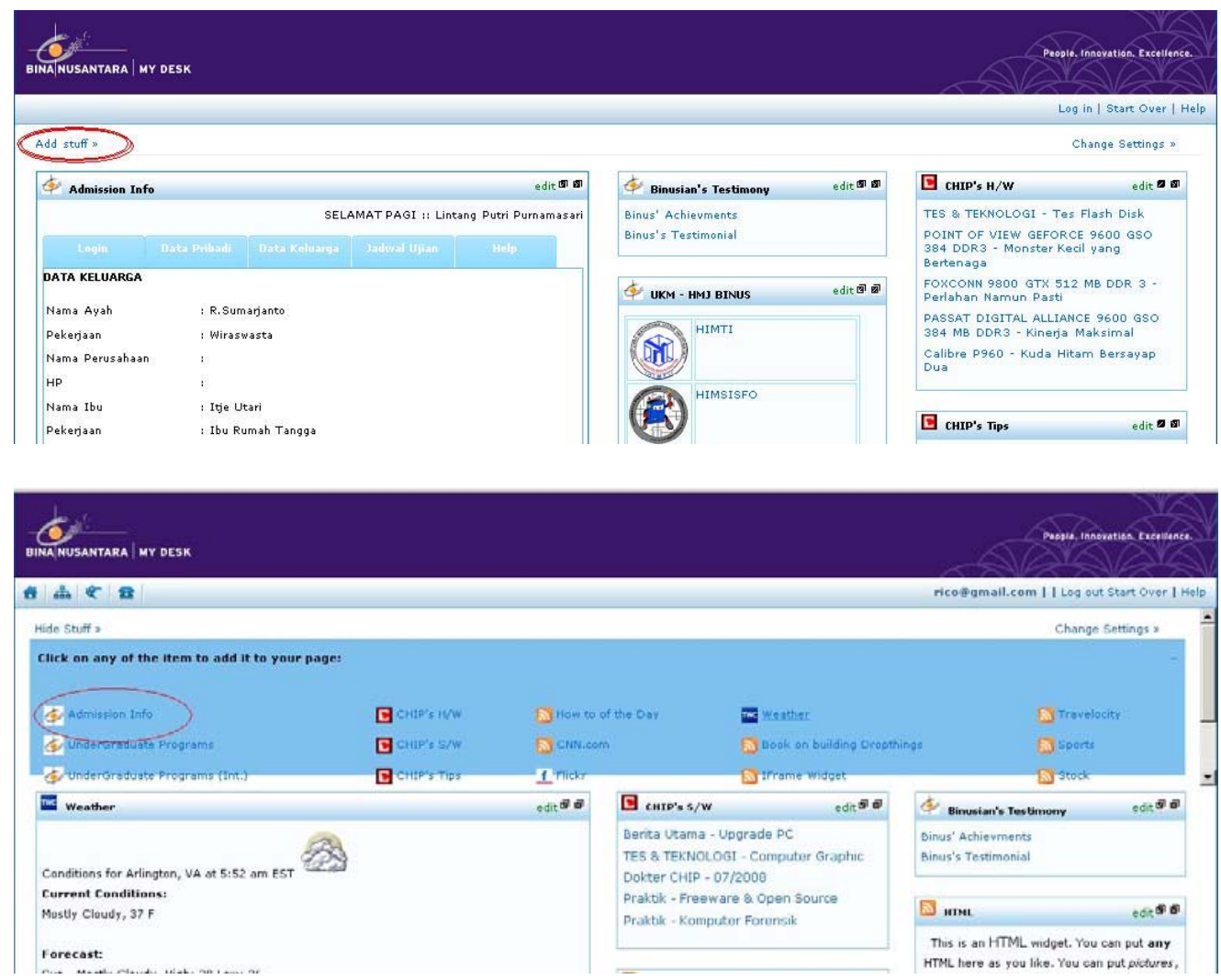

Gambar 8 User Interface Menambah Widget

\section{SIMPULAN}

Berdasarkan penelitian, analisis dan perancangan sistem yang diusulkan tim penulis mengambil kesimpulan sebagai beriku bahwa E-Service yang dikembangkan dapat digunakan oleh BINUS University sebagai competitive advantage atau point unik bagi Binus University dalam upaya pemasaran jasa pendidikan yang disediakan BINUS University. Berdasarkan analisas kuesioner dan wawancara yang telah dilakukan Pengembangan aplikasi e-service portal dapat memberikan memfasilitasi lengkap, aktual dan dibutuhkan bagi potensi calon mahasiswa.serta dapat membantu pemasaran BINUS University dalam memberikan pelayanan yang lebih optimal. Aplikasi harus dijaga agar tetap menark dan ini dapat dikembangkan menjadi sebuah portal yang menyediakan lebih banyak content tidak hanya bagi potensial calon mahasiswa tapi juga bagi keluarga besar BINUS University pada umumnya. Misalnya: Mahasiswa, alumni, dosen dan karyawan.

\section{DAFTAR PUSTAKA}

Prakoso, K. S. (2004) Fundamentals of Portal , http://ikc.unimal.ac.id/umum/kukuh-portal.php, Diakses pada tanggal 22 November 2008.

Lamersdorf, W., Tschammer, V., \& Amarger, S. (2004). Building the E-Service Society: E-Commerce, E-Business, and E-Government International 
Federation for Information Processing. Boston

Laudon K.C., \& Laudon, J. P. (2004). Managing The Digital Firm. Eighth edition Prentice Hall.

Mcleod, R, J. (2001). Sistem Informasi Manajemen. Diterjemahkan oleh Hardi

Sukardi dan Agus Widyantoro. Edisi Ketujuh. Jakarta: Prenhallindo.

O’Brien, J. A. (2004). Management Information Systems. Sixth edition. Northern Arizona : McGrawHill.

Thompson, R., L., \& Cats-Baril, W. (2003). Information Technology \& Management, second edition. McGraw Hill.

Yee, G. (2006). Privacy Protection for E-Service.USA: Idea Group Publishing.

Zabir, O. A. (2008). Building a Web 2.0 Portal with ASP.NET 3.5. Sebastopol: O’Reilly Media, Inc. 